\title{
Pilihan Terapi Empiris Demam Tifoid pada Anak: Kloramfenikol atau Seftriakson?
}

\author{
Sondang Sidabutar, Hindra Irawan Satari
}

Departemen Ilmu Kesehatan Anak, RS Dr Cipto Mangunkusumo, Fakultas Kedokteran Universitas Indonesia, Jakarta

\begin{abstract}
Demam tifoid pada anak besar (lebih dari usia sepuluh tahun) pada umumnya mempunyai gambaran klinis demam tifoid menyerupai dewasa. Demikian juga derajat berat penyakit akan lebih parah dibandingkan pasien anak yang lebih muda. Oleh karena itu, pengamatan keadaan klinis pasien selama mendapat pengobatan harus dievaluasi dengan cermat terutama mengenai parameter keberhasilan pengobatan seperti keadaan umum, suhu, gejala intestinal, komplikasi baik intra maupun ekstra intestinal, hitung leukosit, fungsi hati, dan asupan cairan serta nutrisi. Pemeriksaan biakan darah terhadap Salmonella typhi merupakan baku emas untuk diagnosis demam tifoid. Walaupun pada saat ini telah terdapat berbagai uji diagnostik cepat (rapid diagnostic test) yang dapat dipergunakan untuk pasien rawat jalan, untuk pasien rawat inap harus dilakukan pemeriksaan biakan Salmonella typhi. Selain untuk menegakkan diagnosis, adanya biakan positif sangat berguna untuk menilai apakah pengobatan empiris yang diberikan saat pertama kali pasien datang ke rumah sakit sudah tepat. Perlu diperhatikan bahwa uji resistensi bakteri harus disertakan pada hasil biakan. Hasil uji resistensi diperlukan dalam menilai antibiotik pilihan alternatif apabila pengobatan empiris tidak seperti yang kita harapkan. Kloramfenikol sampai saat ini masih merupakan pengobatan lini pertama untuk demam tifoid pada anak yang dirawat di Departemen Ilmu Kesehatan RS Cipto Mangunkusumo Jakarta. Namun saat ini banyak dilaporkan adanya keadaan multidrug resistance Salmonella typhi (MDSRT), seperti dilaporkan di Pakistan, Mesir, dan Thailand. Maka untuk kasus MDRST diberikan pilihan pengobatan lini kedua yaitu seftriakson atau kuinolon. Namun karena penggunaan kuinolon masih kontroversi untuk anak mengingat dapat menyebabkan artropati, maka seftriakson menjadi pilihan kedua untuk demam tifoid pada anak. (Sari Pediatri 2010;11(6):434-9).
\end{abstract}

Kata kunci: demam tifoid, kloramfenikol, seftriakson, prognosis

\footnotetext{
Alamat korespondensi:

Dr. Hindra Irawan Satari, Sp.A(K), Mtrop.Paed. Divisi Infeksi dan Pediatri Tropis Departemen Ilmu Kesehatan Anak FKUI-RSCM Jl. Salemba no. 6, Jakarta 10430. Telepon: 021-3914126. Fax.021-390 7743
}

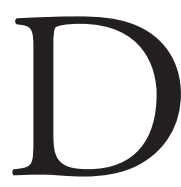

emam tifoid merupakan penyakit infeksi sistemik akut yang mengenai sistem retikuloendotelial, kelenjar limfe saluran cerna, dan kandung empedu. Disebabkan terutama oleh Salmonella enterica serovar typhi $(S$. typhi) dan menular melalui jalur fekal-oral. Demam 
tifoid endemis di negara berkembang khususnya Asia Tenggara. ${ }^{1}$ Sebuah penelitian berbasis populasi yang melibatkan 13 negara di berbagai benua, melaporkan bahwa selama tahun 2000 terdapat 21.650.974 kasus demam tifoid dengan angka kematian 10\%. ${ }^{2}$ Insidens demam tifoid pada anak tertinggi ditemukan pada kelompok usia 5-15 tahun. Indonesia merupakan salah satu negara dengan insidens demam tifoid, pada kelompok umur 5-15 tahun dilaporkan 180,3 per 100,000 penduduk. ${ }^{3,4}$

Pemberian antibiotik empiris yang tepat pada pasien demam tifoid sangat penting, karena dapat mencegah komplikasi dan mengurangi angka kematian. Kloramfenikol, ampisilin, dan kotrimoksazol merupakan antibiotik lini pertama yang telah dipakai selama puluhan tahun sampai akhirnya timbul resistensi yang disebut multidrug resistant Salmonella typhi (MDRST). Beberapa penelitian menunjukkan keunggulan seftriakson sebagai antibiotik terpilih. Faktor biaya, ketersediaan obat, efikasi, kekambuhan, dan MDRST merupakan masalah dalam terapi antibiotik pada demam tifoid, terutama di negara berkembang. ${ }^{5}$

\section{Kasus}

Seorang anak laki-laki, usia 11 tahun, datang ke Poliklinik Umum Departemen Ilmu Kesehatan Anak (IKA), Rumah Sakit Cipto Mangunkusumo (RSCM) Jakarta dengan keluhan utama demam sejak sepuluh hari sebelum dirawat. Demam dirasakan terutama sore dan malam hari, disertai nyeri kepala, mual, nyeri perut, dan nafsu makan menurun. Muntah, batuk, pilek, kesadaran menurun, ataupun kejang disangkal. Pasien mengalami konstipasi namun terkadang diare, sedangkan buang air kecil seperti biasa. Tujuh hari sebelum dirawat pasien berobat ke dokter umum karena keluhan belum berkurang, diberikan simetidin dan kapsul antibiotik yang diminum tiga kali sehari. Lima hari kemudian, pasien berobat ke Puskesmas karena demam semakin tinggi. Pasien diberi obat penurun panas, obat mual, kapsul antibiotik, dan disarankan untuk menjalani pemeriksaan laboratorium. Pemeriksaan darah menunjukkan hemoglobin 12,7 $\mathrm{g} / \mathrm{dL}$, hitung leukosit $5400 / \mu \mathrm{L}$, hitung trombosit $116,000 / \mu \mathrm{L}$, uji Widal S. typhi $H>1 / 1280$, laju endap darah $42 \mathrm{~mm} / \mathrm{jam}$. Pasien kemudian berobat ke Poliklinik Umum Departemen IKA RSCM karena demam semakin tinggi (mencapai $40,3^{\circ} \mathrm{C}$ ) dan anak terlihat lemas.

Pasien adalah anak kedua dari dua bersaudara, berasal dari golongan sosial ekonomi menengah. Riwayat kelahiran dan tumbuh kembang normal, saat ini pasien duduk di sekolah dasar kelas lima. Imunisasi dasar lengkap, kualitas dan kuantitas asupan nutrisi kesan kurang, dan pasien sering jajan di sekolah.

Pada pemeriksaan fisis saat datang ke rumah sakit, pasien tampak sakit sedang, kompos mentis, suhu aksila $38^{\circ} \mathrm{C}$, dan tanda vital lain normal. Berdasarkan status antropometri dan klinis pasien termasuk kategori gizi kurang, dengan berat badan $29 \mathrm{~kg}$ dan tinggi badan $138 \mathrm{~cm}$. Ditemukan coated tongue, hepatomegali, dan nyeri tekan epigastrium. Pemeriksaan fisis lain dalam batas normal. Pemeriksaan darah tepi kadar hemoglobin $11 \mathrm{~g} / \mathrm{dL}$, hitung leukosit $4900 / \mu \mathrm{L}$, hitung trombosit $123,000 / \mu \mathrm{L}$, hitung jenis leukosit (\%) basofil 0 , eosinofil 0 , batang 0 , segmen 72 , limfosit 25 , monosit 3. Pemeriksaan uji serologi (rapid diagnostic test Tubex $^{\circledR}$ ) IgM S. typhi +8 . Diagnosis kerja saat masuk RSCM adalah tersangka demam tifoid dan gizi kurang. Selanjutnya pasien dirawat, tirah baring, diet makanan lunak, pemberian kloramfenikol 4x500 mg. Selama perawatan masih terdapat demam terutama sore dan malam hari yang mencapai suhu $40^{\circ} \mathrm{C}$. Pemeriksaan laboratorium darah pada hari ketiga perawatan menunjukkan kadar hemoglobin 10,4 g/dL, hitung leukosit $3900 / \mu \mathrm{L}$, hitung trombosit $167,000 /$ $\mu \mathrm{L}$. Hasil biakan darah $S$. typhi positif dan sensitif terhadap kloramfenikol, ampisilin, kotrimaksazol, dan seftriakson, sehingga antibiotik kloramfenikol dilanjutkan sampai enam hari. Pada perawatan hari keenam demam masih tinggi, konstipasi, mual, dan asupan nutrisi tidak adekuat. Antibiotik kemudian diganti dengan seftriakson 1x2 gram intravena. Demam turun setelah pemberian seftriakson selama tiga hari, keluhan lain membaik, dan pasien dipulangkan setelah pemberian seftriakson selama lima hari.

\section{Formulasi pertanyaan klinis}

Pengalaman klinis menunjukkan bahwa pemilihan antibiotik sebagai terapi empiris merupakan hal yang penting untuk mengurangi morbiditas dan mortalitas. Beberapa pertimbangan seperti biaya, lama rawat, kepatuhan, dan komplikasi yang timbul mempengaruhi pilihan antibiotik tersebut. Berdasarkan hal tersebut 
diajukan pertanyaan klinis sebagai berikut: "Pada anak besar dengan demam tifoid apakah seftriakson memberi luaran klinis (waktu penyembuhan, kekambuhan, dan efek samping) yang lebih baik dibandingkan kloramfenikol?"

\section{Metode penelusuran literatur}

Prosedur pencarian literatur untuk menjawab masalah klinis, dengan menelusuri pustaka secara online dengan mempergunakan instrumen pencari Pubmed, Google, Yahoo, dan Highwire dengan memakai kata kunci "typhoid fever", "chloramphenicol", "ceftriaxone", dan "treatment" dengan menggunakan batasan: studi yang dilakukan pada manusia, publikasi bahasa Inggris, anak usia 0-18 tahun, kata kunci terdapat pada judul atau abstrak, serta jenis publikasi berupa uji klinis, uji klinis terandomisasi, meta-analisis, dan review. Levels of evidence ditentukan berdasarkan klasifikasi yang dikeluarkan oleh Oxford Centre for Evidence-based Medicine Levels of Evidence. ${ }^{6}$

\section{Hasil penelusuran}

Dengan metode yang telah disebutkan, pada awalnya didapatkan 73 artikel yang memenuhi kriteria. Dalam penelusuran abstrak, didapatkan 19 artikel yang relevan dengan masalah, terdiri atas enam artikel uji klinis, delapan artikel review, dua artikel kohort prospektif, satu studi analisis ekonomi, satu studi deskriptif, dan satu studi potong lintang. Pada masa pra-antibiotik, angka kematian akibat demam tifoid cukup tinggi. Kloramfenikol pertama kali digunakan secara luas tahun 1948 dan penggunaannya dapat menurunkan angka kematian (hingga $<1 \%$ ) dan lama demam (dari 14-28 hari menjadi 3-5 hari). Multidrug resistant Salmonella typhi adalah resistensi terhadap lini pertama antibiotik yang biasa digunakan pada demam tifoid yaitu kloramfenikol, ampisilin, dan kotrimoksazol. Penyebab MDRST adalah pemakaian antibiotik yang tidak rasional (over-used) dan perubahan faktor instrinstik dalam mikroba. ${ }^{8}$

Watson $\mathrm{KC} \mathrm{dkk}^{9}$ melaporkan tentang efikasi kloramfenikol yang diberikan selama 10-12 hari pada 110 pasien demam tifoid. Pasien dibagi menjadi tiga kelompok berdasarkan derajat penyakit (ringan, sedang, dan berat). Pada kelompok berat kloramfenikol diberikan dengan dosis 500 mg tiap 4 jam selama 2-3 hari, dilanjutkan tiap 6 jam sampai demam turun, kemudian 250 mg tiap 6 jam. Pada kelompok ringan dan sedang, diberikan kloramfenikol dosis $250 \mathrm{mg}$ tiap 6 jam sampai demam turun dan dilanjutkan tiap 8 jam. Lama demam turun berkisar 4,1 hari. Efek samping berupa mual dan muntah terjadi pada 5\% pasien. Kekambuhan yang timbul 9-12 hari setelah obat dihentikan terjadi pada $6 \%$ kasus, dan hal ini berhubungan dengan lama terapi yang kurang dari 14 hari (level of evidence 2b).

Seftriakson merupakan antibiotik beta-lactamase dengan spektrum luas, memiliki waktu paruh yang panjang sehingga dapat diberikan 1-2 kali sehari. Efek samping yang mungkin ditemukan adalah reaksi alergi, peningkatan fungsi hati, trombositosis, dan leukopenia. ${ }^{10}$ Acharya $\mathrm{G} \mathrm{dkk}{ }^{11}$ melaporkan bahwa pasien demam tifoid menunjukkan respons klinis yang baik dengan pemberian seftriakson sekali sehari. Lama demam turun rata-rata empat hari, semua hasil biakan menjadi negatif pada hari keempat, dan tidak ditemukan kekambuhan. Hasil laboratorium menunjukkan kadar hemoglobin dan hitung leukosit normal, serta tidak ditemukan gangguan fungsi hati dan ginjal (level of evidence 2b). ${ }^{11}$

Penelitian uji klinis acak terkontrol oleh Islam A $\mathrm{dkk}^{12}$ membandingkan efikasi pemberian seftriakson sekali sehari selama lima hari dengan kloramfenikol selama empatbelas hari. Subjek penelitian terdiri dari 59 pasien dengan hasil biakan positif S. typhi dan sensitif terhadap kedua antibiotik. Seftriakson diberikan dengan dosis $75 \mathrm{mg} / \mathrm{kg} / \mathrm{hari}$ sedangkan kloramfenikol $60 \mathrm{mg} / \mathrm{kg} /$ hari sampai demam turun, lalu dosis diturunkan menjadi $40 \mathrm{mg} / \mathrm{kg} / \mathrm{hari}$ sampai total 14 hari. Perbaikan hasil kultur berbeda bermakna pada kedua kelompok. Pada hari ketiga, 60\% hasil biakan positif ditemukan pada kelompok yang mendapat kloramfenikol sedangkan pada kelompok seftriakson tidak lagi ditemukan hasil biakan positif $(\mathrm{P}=0,001)$. Nilai median hematokrit dan leukosit yang diukur pada hari keempatbelas secara bermakna lebih rendah pada kelompok kloramfenikol $(\mathrm{p}=0,001)$. Angka kekambuhan pada penelitian ini tidak dapat dipastikan karena tidak semua pasien kontrol setelah dipulangkan (level of evidence 1b). ${ }^{12}$

Moosa $\mathrm{A} \mathrm{dkk}^{13}$ melaporkan sebuah uji klinis acak terkontrol pada 59 demam tifoid anak. Seftriakson diberikan dengan dosis $80 \mathrm{mg} / \mathrm{kg} /$ hari selama lima hari sedangkan kloramfenikol diberikan dengan 
dosis $50-100 \mathrm{mg} / \mathrm{kg} /$ hari selama tiga minggu. Hasil penelitian mendapatkan bahwa lama demam turun, dan kekambuhan tidak berbeda bermakna pada kedua kelompok. Penelitian tersebut menunjukkan efikasi kedua antibiotik yang tidak jauh berbeda namun pemberian seftriakson selama lima hari saja dapat mengurangi biaya pengobatan, dan mengurangi trauma psikologis pada anak yang menjalani perawatan rumah sakit yang berkepanjangan (level of evidence 2b). ${ }^{13}$

Penelitian uji klinis acak terkontrol oleh Acharya G $\mathrm{dkk}^{14}$ membandingkan efikasi seftriakson selama tiga hari dengan kloramfenikol selama empatbelas hari. Penelitian dilakukan pada 46 pasien dengan biakan darah positif S.typhi dan S. paratyphi. Seftriakson diberikan dengan dosis $50 \mathrm{mg} / \mathrm{kg} /$ hari, sedangkan kloramfenikol $60 \mathrm{mg} / \mathrm{kg} /$ hari sampai demam turun dan dilanjutkan dengan dosis $40 \mathrm{mg} / \mathrm{kg} /$ hari sampai total empatbelas hari. Perbaikan klinis yang terjadi pada kedua kelompok tidak berbeda bermakna. Efek samping pemberian seftriakson seperti urtikaria, flebitis, dan kolestasis tidak ditemukan. Efek samping trombositopenia dan leukopenia secara bermakna terjadi pada kelompok yang mendapatkan kloramfenikol $(p<0,05)$. Hasil mendukung pemberian seftriakson jangka pendek di negara berkembang dalam hal mengurangi biaya rawat (level of evidence 1b). ${ }^{14}$

Suatu penelitian uji klinis acak terkontrol mengenai durasi pemberian seftriakson dilakukan oleh Tatli MM dkk ${ }^{15}$ Penelitian dilakukan pada 72 pasien dengan hasil biakan positif $S$. typhi. Seftriakson diberikan dengan dosis $75 \mathrm{mg} / \mathrm{kg} /$ hari maksimal $2 \mathrm{~g} /$ hari sampai lima hari bebas demam dan kloramfenikol diberikan dengan dosis $75 \mathrm{mg} / \mathrm{kg} /$ hari selama empatbelas hari. Terdapat perbedaan bermakna pada lama demam turun dan kekambuhan $(p=0,04)$. Pada kelompok kloramfenikol rata-rata bebas demam 4,2 hari dengan angka kekambuhan 14,2\%. Pada kelompok seftriakson ratarata bebas demam 5,2 hari tanpa adanya kekambuhan, dan rata- rata pemberian selama 10 hari (8-12 hari). Efek samping obat tidak ditemukan pada kedua kelompok. Penelitian menyimpulkan bahwa lama terapi penting untuk mencegah kekambuhan (level of evidence 16$) .15$

Kumar $\mathrm{R}$ dkk $^{16}$ melaporkan sebuah penelitian uji klinis acak terkontrol mengenai MDRST. Kloramfenikol diberikan sebagai terapi awal dan setelah terbukti terdapat MDRST antibiotik diganti menjadi ofloksasin (20 mg/kg/hari) atau seftriakson (100 mg/ kg/hari). Penelitian mendapatkan kasus MDRST 70\%.
Lama demam turun berbeda bermakna antara kedua kelompok $(\mathrm{p}<0,05)$. Pemantauan sampai tiga bulan pasca rawat tidak ditemukan kekambuhan pada kedua kelompok. Pada kasus MDRST anak, seftriakson merupakan antibiotik pilihan karena aman (level of evidence 1b). ${ }^{16}$

Sebuah uji klinis acak terkontrol oleh Girgis NI $\mathrm{dkk}^{17}$ membandingkan efikasi, keamanan, dan biaya pemberian sefiksim, seftriakson, dan aztreonam pada MDRST. Sefiksim diberikan dengan dosis 7,5 mg/kg diberikan dua kali sehari selama 14 hari, seftriakson $50-70 \mathrm{mg} / \mathrm{kg}$ satu kali sehari selama 5 hari, dan aztreonam $50-70 \mathrm{mg} / \mathrm{kg}$ tiga kali sehari selama 7 hari. Lama demam turun berbeda bermakna pada ketiga obat. Seftriakson menurunkan demam setelah 3,9 hari, dibanding sefiksim 5,3 hari, dan aztreonam 5,5 hari $(\mathrm{p}<0,05)$. Pada pemantuan hingga empat minggu pasca rawat, kekambuhan pada kelompok yang mendapat seftriakson 5\%, dan pada kelompok yang mendapat sefiksim dan aztreonam masing-masing 6\%. Pada ketiga kelompok tidak ditemukan efek samping obat yang berarti. Penelitian menunjukkan bahwa seftriakson memiliki efikasi yang lebih baik dan dapat menurunkan biaya rawat karena diberikan dalam waktu yang singkat (level of evidence 1b). ${ }^{17}$

Musnelina $\mathrm{L} \mathrm{dkk}^{18}$ melaporkan sebuah studi analisis ekonomi mengenai efektivitas biaya pengobatan demam tifoid anak yang dirawat di rumah sakit. Efisiensi biaya yang dinilai adalah biaya perawatan, pemeriksaan laboratorium, dokter, dan obat. Lama hari rawat kelompok yang mendapat kloramfenikol adalah 6,5 hari, sedangkan kelompok seftriakson selama 4,4 hari. Penelitian mendapatkan bahwa efisiensi biaya pada kelompok yang mendapatkan seftriakson lebih baik secara bermakna dibandingkan dengan kelompok yang mendapatkan kloramfenikol (level evidence 2b). ${ }^{18}$

\section{Pembahasan}

Berdasarkan hasil penelusuran literatur yang ada, studi terkini lebih menganjurkan pemberian seftriakson dibandingkan kloramfenikol untuk pasien demam tifoid yang dirawat di rumah sakit. Beberapa studi menunjukkan bukti luaran yang lebih baik tentang penggunaan seftriakson sebagai terapi empiris pada demam tifoid. Kriteria yang sebaiknya dipenuhi oleh antibiotik empiris antara lain cara pemberian

Sari Pediatrī, Vol. 11, No. 6, April 2010 
mudah bagi anak, tidak mudah resisten, efek samping minimal, dan telah terbukti efikasi secara klinis. ${ }^{19}$ Pada kasus kami, usia pasien sesuai dengan predileksi usia tersering, dan terdapat riwayat jajan yang merupakan sumber penularan penyakit. Perjalanan penyakit pasien telah memasuki minggu kedua demam, dan terdapat gangguan gastrointestinal yang menyebabkan asupan tidak adekuat dan anak terlihat lemas. Pada pasien dengan perjalanan klinis yang telah memasuki minggu kedua dengan gejala gastrointestinal yang nyata, terapi peroral tidak ideal.

Lama demam turun (time of fever defervescence) merupakan salah satu parameter keberhasilan pengobatan. Demam yang tetap tinggi menunjukkan kemungkinan komplikasi, fokus infeksi lain, resistensi S. typhi, atau salah diagnosis. ${ }^{19}$ Berdasarkan hasil uji resistensi bakteri terhadap berbagai antibiotik, tidak ditemukan adanya MDRST dari isolat yang diperiksa sejak tahun 2003-2007 di laboratorium Mikrobiologi Fakultas Kedokteran Universitas Indonesia. ${ }^{20}$ Demam tifoid anak dengan MDRST secara klinis akan menunjukkan respon yang lambat terhadap terapi (lebih dari 48-72 jam), lebih sering mengalami komplikasi, dan kemungkinan menjadi fatal lebih besar. Antibiotik terpilih untuk MDRST adalah siprofloksasin dan seftriakson. Pemberian siprofloksasin pada anak usia $<18$ tahun masih diperdebatkan karena adanya potensi artropati, sehingga seftriakson lebih direkomendasikan. ${ }^{8,5}$ Pasien kami memiliki kepatuhan minum obat yang baik, tidak ditemukan fokus infeksi lain, dan dosis antibiotik kloramfenikol yang diberikan telah sesuai. Secara invitro, S. typhi menunjukkan sensitivitas terhadap kloramfenikol, namun respons yang ditunjukkan pasien tidak sesuai. Riwayat pemakaian antibiotik peroral selama rawat jalan dan respons yang lambat terhadap kloramfenikol di rumah sakit, menunjukkan kemungkinan adanya resistensi, sehingga antibiotik seharusnya dapat diganti lebih awal. ${ }^{1}$

Perbedaan yang mendasar pada kedua antibiotik ini adalah lama demam turun lebih cepat sehingga lama terapi lebih singkat, efek samping lebih ringan, dan angka kekambuhan yang lebih rendah pada penggunaan seftriakson dibandingkan kloramfenikol. Durasi terapi seftriakson bervariasi antara 3-10 hari dengan waktu demam turun rata-rata empat hari, dan aman diberikan pada anak dengan dosis antara $50-100 \mathrm{mg} / \mathrm{kg} /$ hari. ${ }^{12,13,15,16}$ Efek samping yang mungkin ditemukan karena pemberian kloramfenikol adalah supresi sumsum tulang. ${ }^{13,15}$ Harga seftriakson lebih mahal dibanding kloramfenikol, namun lama rawat yang lebih pendek sangat mengurangi biaya pengobatan. ${ }^{14,18,19}$ Pasien mengalami efek samping kloramfenikol berupa supresi sumsum tulang. Setelah pemberian seftriakson dengan dosis $80 \mathrm{mg} / \mathrm{kg}$ berat badan/hari dengan maksimal dosis $2 \mathrm{~g} /$ hari, demam turun setelah hari ketiga terapi. Seftriakson dilanjutkan sampai lima hari pengobatan, terbukti memberikan respon klinis yang baik.

\section{Kesimpulan}

Antibiotik empiris yang tepat sangat bermakna menurunkan morbiditas dan mortalitas. Pemberian seftriakson sebagai terapi empiris pada pasien demam tifoid secara bermakna dapat mengurangi lama pengobatan dibandingkan dengan pemberian jangka panjang kloramfenikol. Hal lain yang menguntungkan adalah efek samping dan angka kekambuhan yang lebih rendah, serta lama demam turun yang lebih cepat. Pengetahuan dan penilaian klinis yang baik diperlukan dalam memilih terapi empiris yang tepat terutama bila fasilitas uji resistensi tidak memadai. Seftriakson terbukti dapat dijadikan sebagai antibiotik pilihan utama pada kasus MDRST.

\section{Daftar Pustaka}

1. Stephens I, Levine MM. Management of typhoid fever in children. Pediatr Infect Dis 2002;21:157-9.

2. Crump JA, Luby SP, Mintz ED. The global burden of typhoid fever. Bull World Health Organ 2004;82:346-53.

3. Ochiai RL, Camilo J, Acosta CJ, Holliday DMC, Baiqing D, Bhattacharya SK, dkk. Study of typhoid fever in five Asian countries: disease burden and implications for controls. Bull World Health Organ 2008;86:260-8.

4. Retnosari S, Tumbelaka AR, Akib AP, Hadinegoro SRS. Clinical and laboratory features of typhoid fever in childhood. Paediatr Indones 2001;4:149-54.

5. Background document: The diagnosis, treatment and prevention of typhoid fever. Geneva: WHO;2003.

6. Oxford Centre of Evidence-based Medicine. Oxford Centre for Evidence-based Medicine Levels of Evidence (March 2009). Diunduh dari: http://www.cebm.net/index. asox?o=1025. Diakses tanggal 9 Juni 2009.

7. Khan MA, Yousaf MN, Mahmood T. Current trends 
in the management of typhoid fever. Gomal Journal of Medical Sciences 2004;2:59-63.

8. Hadinegoro SR. Masalah multidrug resistance pada demam tifoid anak. Cermin Dunia Kedokteran 1999; $124: 5-8$.

9. Watson KC. Chloramphenicol in typhoid fever: a review of 110 cases. Am J Trop Med Hyg 1954;6:526-32 .

10. Harrison CJ, Bratcher D. Cephalosporins: a review. Pediatr Rev 2008;29;264-73.

11. Acharya G, Revoisier C, Butler T, Ho M, Tiwari M, Klaus SK, dkk. Pharmacokinetics of ceftriaxone. Antimikcrob Agents Chemother 1998;38: 241-8.

12. Islam A, Buttler T, Kabir I, Alam NH. Treatment of typhoid fever with ceftriaxone for 5 days or chloramphenicol for 14 days: a randomized clinical trial. Antimicrob. Agents Chemother 1993;37:1572-5 .

13. Moosa A, Rubidge CJ. Once daily ceftriaxone vs chloramphenicol for treatment of typhoid fever in children. Pediatr Infect Dis J 1989;8:696-9.

14. Acharya G, Buttler T, Ho M, Sharma PR, Tiwari M, Adhikari RK dkk. Treatment of typhoid fever: randomized trial of a three-day course of Ceftriaxone versus a fourteen day course of chloramphenicol. Am. J Trop Med Hyg 1995;52:162-5.

15. Tatli MM, Guler G, Kosecik M, Yilmaztatli A. Treatment of typhoid with a flexible-duration of ceftriaxone compared with 14-day treatment with chloramphenicol. Int J Antimicrob Agents 2003;21:350-3.

16. Kumar R, Gupta N, Shalini. Multidrug- resistant typhoid fever. Int J Pediatr 2007:24:39-42.

17. Girgis NI, Sultan Y, Hammad O, Farid Z. Comparison of the efficacy, safety and cost of cefixime, ceftriaxone and aztreonam in the treatment of multidrug-resistant Salmonella typhi septicemia in children. Pediatr Infect Dis J 1995;14:603-5.

18. Musnelina L, Afdhal AF, Gani A, Andayani P. Analisis efektivitas biaya pengobatan demam tifoid anak menggunakan kloramfenikol dan seftriakson di rumah sakit Fatmawati Jakarta tahun 2001-2002. Makara 2004;8:59-64.

19. Hadinegoro SR. Strategi pengobatan demam tifoid pada anak. Dalam: Akib AAP, Tumbelaka AR, Matondang CS, penyunting. Naskah lengkap Pendidikan Kedokteran Berkelanjutan Bagian Ilmu Kesehatan Anak XLIV. Jakarta: BP FKUI; 2001.h.105-16.

20. Mirawati TS, Karuniawati A, Ningsih I, Ariyani k, Conny R, Hutabarat T, dkk. Hasil uji resistensi bakteri terhadap berbagai antibiotika tahun 2003-2007. Di laboratorium Klinik Mikrobiologi Fakultas Kedokteran Universitas Indonesia, Jakarta. 